\title{
RADIO-ACTIVE DI-IODOFLUORESCEIN IN THE DIAGNOSIS OF INTRA-OCULAR TUMOURS*†
}

\author{
BY
}

\author{
P. D. TREVOR-ROPER, K. A. NEWTON, AND J. P. NICHOLSON
}

London

THE use of radio-active dyes in the localization of brain tumours has been described in recent years by various authors. For example, Boyack and others (1948) found that di-iodofluorescein in which the iodine had been rendered radio-active was preferentially taken up by brain-tumour tissue, so that the position of the tumour could be determined by Geiger-counter measurements made from outside the skull. In a series of 104 cases, Ashkenazy and others (1947) claimed 95 per cent. success in the localization of tumours to one particular quadrant of the brain.

Recently Belcher and Evans (1951) and de Winter (1951) in a very detailed investigation, using the far more sensitive scintillation counter, have failed to confirm these results, nor could the selective uptake of the dye in neoplastic tissue be observed in any one of the specimens removed surgically. They concluded that, owing to variations in the vascular character of the brain tissues and radiation from other body organs, even a 20 per cent. change in count-rate due to concentration of activity in a brain tumour, would prove difficult to detect.

In ocular tumours the circumstances are rather different. In the first place, we are dealing with a tissue mass which, although much smaller in volume, is located so superficially that the counter can be applied within $3 \mathrm{~cm}$. of the tumour itself; and in the second place, it is not the localization of the tumour which is sought, that being usually all too apparent ophthalmoscopically, but assistance in the all-important and often perplexing differential diagnosis of such a mass. Although the reason for this concentration in neoplastic tissues and its preference for those of the central nervous system is quite obscure, it seemed likely that both of the important malignant intra-ocular neoplasia, and especially the retinoblastoma, might share this predilection, both being as a rule richly supplied with vessels. At any rate the paramount importance of such a diagnostic test, if it proved successful in determining whether an eye should be removed, seemed to justify this investigation, in spite of discouraging reports by Belcher and Evans, and by de Winter. It should be added that Davis (1951) has already found positive counts in two cases with large malignant melanomata.

- Received for publication August 9, 1952.

†Dedicated to Professor Lindner on the occasion of his 70th birthday. 
Thomas and others (1952) have used another radio-isotope (phosphorus 32) for the same purpose. The $\beta$-rays emitted by phosphorus 32 have a maximum range in tissue of about $7 \mathrm{~mm}$., which means that a concentration of the isotope lying at a depth greater than this would go undetected. The authors point out that by using this isotope the effects of the active material lying at a greater depth or circulating in the blood are thereby obviated and this should result in a clearer picture being obtained. The disadvantage of this method lies in the fact that lesions in the posterior part of the eye were only made reasonably accessible to observation by rotation and fixation of the eye. These disadvantages are obviated by the use of di-iodofluorescein incorporating radio-active iodine 131 and emitting $\gamma$ rays which can be detected after they have passed through several centimetres of tissue.

\section{Technique}

To avoid radiation hazard it was thought advisable to use an amount of dye containing not more than $1 \mathrm{mc}$. radio-iodine for each patient. The dye, in approximately $2 \mathrm{ml}$. solution, was injected intravenously, and, following the practice of other workers, counting* was begun from 2 to 4 hours after injection. The counter tube (type G.M. 4) was shielded laterally by $1 \mathrm{~cm}$. lead to absorb radiation from other parts of the body as far as possible. The aperture of this lead shield was $2.5 \mathrm{~cm}$.

TABLE

ANALYSIS OF CASES TESTED (1-9 Malignant

\begin{tabular}{|c|c|c|c|c|c|c|c|c|c|c|}
\hline \multirow{2}{*}{$\begin{array}{l}\text { Case } \\
\text { No. }\end{array}$} & & \multirow{2}{*}{$\begin{array}{l}\text { Age } \\
\text { (yrs) }\end{array}$} & \multicolumn{7}{|c|}{ Clinical Details } & \multirow{2}{*}{$\underset{(\mathrm{mc} .)}{\text { Amount Injected }}$} \\
\hline & & & Side & Site & Extension & Size & $\begin{array}{l}\text { Reti- } \\
\text { culin }\end{array}$ & $\begin{array}{l}\text { Blood } \\
\text { sinuses }\end{array}$ & $\begin{array}{l}\text { Pig- } \\
\text { ment }\end{array}$ & \\
\hline 1 & $\mathrm{~F}$ & 32 & L & Macula & Sclera & $t+$ & + & ++ & + & $0 \cdot 74$ \\
\hline 2 & $\mathrm{~F}$ & 82 & $\mathbf{R}$ & Equator & $\begin{array}{l}\text { Ciliary body } \\
\text { and anterior } \\
\text { chamber }\end{array}$ & ++ & + & +4 & $+\cdots$ & $0 \cdot 37$ \\
\hline 3 & $\mathrm{~F}$ & 51 & $\mathbf{R}$ & Macula & Sclera & + & ++ & $+\cdot+$ & -1 & $1 \cdot 0$ \\
\hline 4 & $\mathrm{~F}$ & 50 & $\mathbf{R}$ & Limbus & Sclera & - & - & - & t+t & $0 \cdot 8$ \\
\hline 5 & $\mathrm{~F}$ & 68 & $\mathbf{R}$ & & Ciliary & + & - & - & - & 1 \\
\hline 6 & $\mathrm{~F}$ & 60 & L & Equator & Presumed non- & - & - & - & - & 1 \\
\hline $\begin{array}{l}7 \\
8 \\
9\end{array}$ & $\begin{array}{c}\mathbf{M} \\
\mathbf{M} \\
\mathbf{F}\end{array}$ & $\begin{array}{l}60 \\
65 \\
61\end{array}$ & $\begin{array}{l}\mathbf{L} \\
\mathbf{R} \\
\mathbf{L}\end{array}$ & $\begin{array}{l}\text { Disk } \\
\text { Quadrant } \\
\text { Lower equator }\end{array}$ & Sclera & $\begin{array}{l}++ \\
++ \\
-\end{array}$ & $\begin{array}{l}++ \\
++ \\
-\end{array}$ & $\begin{array}{l}++ \\
++ \\
-\end{array}$ & $\begin{array}{l}+++ \\
++ \\
-+\end{array}$ & $\begin{array}{l}1 \\
0 \cdot 8 \\
1\end{array}$ \\
\hline 10 & $\mathrm{~F}$ & $\begin{array}{c}6 \\
\text { mths }\end{array}$ & L & Nasal & - & - & - & - & - & $0 \cdot 1$ \\
\hline 11 & $\mathbf{M}$ & $\begin{array}{l}10 \\
\text { wks }\end{array}$ & $\mathbf{R}$ & Retrolental & $\begin{array}{l}\text { Presumed non- } \\
\text { malignant }\end{array}$ & - & - & - & - & $0 \cdot 1$ \\
\hline
\end{tabular}

* The count-rate meter is made by Panax Equipment, Ltd. 
In all cases the count rates were quite low, in some cases so low as to be almost beyond the range of the instrument; and the authors feel that too much reliance should not be placed on any asymmetry between the count rates over each eye, quite apart from the possible physiological significance of such differences. Unfortunately a scintillation counter was not available at the time when these experiments were performed.

\section{Clinical Results}

Eight cases of malignant melanomata, and one of retinoblastoma were investigated. One further case of each (Cases 6 and 11) was also tested, but the diagnosis was too uncertain to justify removal of the eye, and the subsequent absence of growth of the tumour in each case has confirmed their non-malignant nature; they are, however, included in the Table below, since their findings have some relevance as controls.

Malignant Melanomata.-These varied in size from a small limbal nodule (Case 4) to which the counter could be directly applied, to several that had extended well into the vitreous cavity, and one (Case 2) that had invaded the anterior chamber.

Case 4 was of especial interest in that there was no increase in the counting rate over the tumour as compared with the corresponding point on the other

Melanoma; 10 and 11 Retinoblastoma)

\begin{tabular}{|c|c|c|c|c|c|c|c|c|c|c|}
\hline \multicolumn{8}{|c|}{ Count Rates (min.) } & \multirow{3}{*}{$\begin{array}{l}\text { Thyroid } \\
\text { Count }\end{array}$} & \multirow{3}{*}{ Thigh Count } & \multirow{3}{*}{ Remarks } \\
\hline \multicolumn{2}{|c|}{$\begin{array}{l}\text { Over } \\
\text { to eye }\end{array}$} & \multicolumn{2}{|c|}{$\begin{array}{l}\text { Below } \\
\text { to eye }\end{array}$} & \multicolumn{2}{|c|}{$\begin{array}{l}\text { Above } \\
\text { to eye }\end{array}$} & \multicolumn{2}{|c|}{$\begin{array}{l}\text { Lateral } \\
\text { to eye }\end{array}$} & & & \\
\hline $\mathbf{L}$ & $\mathbf{R}$ & $\mathrm{L}$ & $\mathbf{R}$ & $\mathbf{L}$ & $\mathbf{R}$ & $\mathbf{L}$ & $\mathbf{R}$ & & & \\
\hline $\begin{array}{r}260 \\
30\end{array}$ & $\begin{array}{r}200 \\
60\end{array}$ & & & $\begin{array}{r}180 \\
40\end{array}$ & $\begin{array}{r}180 \\
90\end{array}$ & 200 & 250 & 600 & 250 & $\begin{array}{l}\text { No significant difference } \\
\text { Slight increase on right } \\
\text { Count rate very low }\end{array}$ \\
\hline $\begin{array}{l}180 \\
900 \\
700\end{array}$ & $\begin{array}{l}180 \\
900 \\
700\end{array}$ & $\begin{array}{l}180 \\
700\end{array}$ & $\begin{array}{l}200 \\
700\end{array}$ & $\begin{array}{l}150 \\
800\end{array}$ & $\begin{array}{l}140 \\
800\end{array}$ & $\begin{array}{l}150 \\
600 \\
750\end{array}$ & $\begin{array}{l}150 \\
1050 \\
750\end{array}$ & $\begin{array}{c}500 \\
1600\end{array}$ & $\begin{array}{c}300 \\
1200\end{array}$ & $\begin{array}{l}\text { No significant difference } \\
\text { See note below } \\
\text { No significant difference }\end{array}$ \\
\hline 600 & 600 & & & & & 600 & 600 & 1000 & 300 & No significant difference \\
\hline $\begin{array}{l}500 \\
200 \\
450\end{array}$ & $\begin{array}{l}500 \\
200 \\
500\end{array}$ & $\begin{array}{l}500 \\
150 \\
800\end{array}$ & $\begin{array}{l}500 \\
150 \\
850\end{array}$ & $\begin{array}{l}450 \\
140 \\
450\end{array}$ & $\begin{array}{l}450 \\
150 \\
550\end{array}$ & $\begin{array}{l}450 \\
120 \\
450\end{array}$ & $\begin{array}{l}550 \\
150 \\
650\end{array}$ & $\begin{array}{c}550 \\
350 \\
1000\end{array}$ & $\begin{array}{l}250 \\
150 \\
800\end{array}$ & $\begin{array}{l}\text { No significant difference } \\
\text { No significant difference } \\
\text { No significant difference }\end{array}$ \\
\hline 600 & 550 & 650 & 850 & 500 & 600 & 600 & 700 & 900 & 650 & $\begin{array}{l}\text { Higher counts on right } \\
\text { Right eye enucleated }\end{array}$ \\
\hline 2900 & $\begin{array}{l}2700 \\
2900\end{array}$ & - & - & - & 一 & - & - & - & 一 & $\begin{array}{l}\text { No significant difference } \\
\text { Other readings not } \\
\text { possible }\end{array}$ \\
\hline
\end{tabular}


eye, but over an area between the right auditory meatus and the right outer canthus the count rate was some 50 per cent. greater than over the left side.

In only one of this small series of eleven cases (Case 2) was there a significant asymmetry in the counts, and unfortunately these readings were near the limits of sensitivity of the instrument. In one other case (Case 4) the increased uptake was observed not over the tumour itself but posterior to it, and in another (Case 9) slightly higher readings were found over the unaffected eye.

It is interesting to note that the count rate over the thyroid gland did not greatly exceed that over the thigh, which shows that the iodine incorporated in the dye is not in a form which is readily taken up by the gland. This seems to indicate that the test should involve little radiation hazard to the thyroid, because of selective iodine concentration.

Retinoblastoma.-This single case can give little indication as to the possible use of radio-active testing as a diagnostic measure, but the practical difficulties of intravenous injection and exact application of the counter to a small and struggling infant hardly encourage the use of this method if further results are as negative as that recorded here.

As a final discouragement against its routine use in diagnosis it may be added that there is an inevitable difficulty in obtaining adequate doses of the radio-active drug to coincide with the discovery of such rare intra-ocularo tumours, since neither can wait for the other-the di-iodofluorescein losing its potency, and the tumour progressing.

\section{Summary}

The selective uptake of the radio-active dye by the melanoma is very small or negligible as compared with that in the rest of the body, and the authors do not feel that this technique can be recommended as a routine diagnostic procedure.

Our acknowledgements are due to the surgeons of the Moorfields, Westminster and Central Eye Hospital for permission to examine their patients, to Dr. Norman Ashton, Director of Pathology at the Institute of Ophthalmology, for the pathological reports, and to Sir Stanford Cade, who is in charge of the Isotope Unit at the Westminster Hospital, for permission to undertake this investigation.

\section{REFERENCES}

Ashkenazy, M., LeRoy, G. V., Fields, T., and Davis, L. (1949). J. Lab. clin. Med., 34, 1580. BelCher, E. H., and EvaNs, H. D. (1951). Brit. J. Radiol., 24, 272.

BoyaCK, G., Moore, G. E., and Clausen, D. F. (1948). Nucleonics, 3, No. 4, p. 62.

DAVIS, L. (1951). Personal communication.

Thomas, C. I., Krohmer, J. S., and StoraAsl, J. P. (1952). Arch. Ophthal., Chicago, 47, 276. DE WINTER, J. G. (1951). Ibid., 24, 280. 